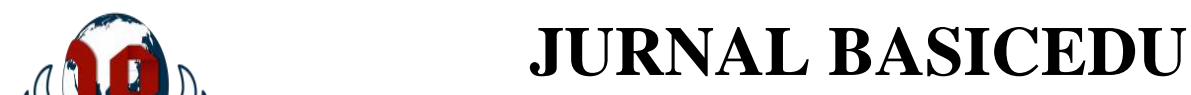

Volume 5 Nomor 4 Tahun 2021 Halaman 1825 - 1833

Research \& Learning in Elementary Education

https://jbasic.org/index.php/basicedu

PAIVERSITAS

\title{
Strategi Mnemonic Sebagai Solusi Untuk Pengayaan Kosa Kata Pada Anak Tunarungu Di Sekolah Dasar
}

\author{
Zaenuri $^{1 凶}$, Maemonah $^{2}$ \\ Universitas Islam Negeri Sunan Kalijaga, Indonesia ${ }^{1,2}$ \\ E-mail: nurizae07@ gmail.com¹, maimunah@uin-suka.ac.id ${ }^{2}$
}

\begin{abstract}
Abstrak
Anak tunarungu adalah anak yang mengalami gangguan pendengaran baik pada taraf ringan hingga berat atau dapat disebut tuli atau deaf. Tujuan dari penelitian ini adalah untuk menawarkan strategi mnemonic keyword sebagai strategi yang tepat untuk meningkatkan pengayaan kosakata pada anak tunarungu yang tentu saja mengalami hambatan terhadap kosakata karena mengalami gangguan pendengaran. Metode yang digunakan adalah metode studi pustaka dengan pendekatan kualitatif deskriftif. Teknik pengumpulan data yang dilakukan peneliti berdasarkan buku-buku pustaka serta hasil penelitian terdahulu yang telah dilakukan. Hasil penelitian yang di dapat peneliti dengan menggunakan metode studi pustaka, strategi mnemonic keyword sangat baik dan efektif digunakan oleh guru sebagai solusi untuk meningkatkan kosakata pada anak tunarungu. Dengan strategi mnemonic keywords, peneliti berharap guru-guru yang menjadi pengajar tunarungu tidak kesulitan mencari strategi yang tepat untuk meningkatkan pengayaan kosakata pada anak tunarungu. Sehingga kosakata yang dimiliki anak-anak tunarungu dapat setara dengan anak-anak normal lainnya.
\end{abstract}

Kata Kunci: Strategi, Tunarungu, Kosakata

\begin{abstract}
Children with hearing impairment are children who have a loss of hearing in both mild to severe levels or can be called deaf or someone who has hearing disorders. The purpose of this study is to propose a mnemonic keyword strategy as an appropriate strategy to increase the vocabulary enrichment of hearing impairment children who naturally experience barriers of vocabularies due to hearing loss. The method used is a literature study method with a descriptive qualitative approach. Data collection techniques were conducted by researchers based on literature books and the result of previous research that has been done. Together with the mnemonic keyword strategy, the researchers hope that teachers who become hearing impairment teachers will have no trouble finding the appropriate strategy to improve vocabulary enrichment for children who are unable to hear. So the vocabulary of children with hearing impairment is equal to other normal children.
\end{abstract}

Keywords: Strategy, Hearing Impairment, Vocabulary

Copyright (c) 2021 Zaenuri, Maemonah

Corresponding author :

Email: nurizae07@gmail.com

DOI : $\quad$ https://doi.org/10.31004/basicedu.v5i4.1038 


\section{PENDAHULUAN}

Secara kodrati semua manusia mempunyai berbagai macam kebutuhan, tak terkecuali anak yang berkebutuhan khusus, salah satu diantaranya kebutuhan yang juga penting yaitu pendidikan. Dengan terpenuhi kebutuhan akan pendidikan anak bisa untuk mengurusi dirinya sendiri dan dapat melepaskan ketergantungan dari orang lain. (Abdullah 2013,1) . Anak berkebutuhan khusus disini adalah anak tunarungu. Istilah lain dari tunarungu ini digunakan pada orang yang mengalami gangguan pendengaran mencakup tuli dan kurang dengar. Tunarungu diartian sebagai suatu keadaan kehilangan pendengaran yang mengakibatkan seorang tidak dapat menerima dari berbagai rangsangan, terutama indera pendengaranya (HarwantiNoviandari dan Mursidi 2019, 42).

Keterampilan berbahasa memiliki empat aspek. Keterampilan berbicara, menulis, menyimak dan membaca, keterampilan berbahasa ini juga nantinya akan berkaitan dengan pemerolehan bahasa. Pemerolehan bahasa bahasa dimulai beberapa bulan setelah seorang bayi lahir. Perolehan bahasa tentu sangat berpengaruh terhadap kosakata yang dimiliki oleh anak tunarungu. Menurut Chaer pemerolehan bahasa adalah proses yang berlangsung di dalam otak seorang anak-anak ketika memperoleh bahasa ibunya atau pertamanya. (Chaer; 2009, 167). Bahasa merupakan alat yang digunakan oleh seorang manusia untuk bisa menunjang kehidupan dalam komunikasi antara manusia lainnya baik tulisan ataupun lisan. Felicia mengatakan penunjang untuk melakukan komunikasi ini adalah kemampuan berbahasa. Terhambatnya perkembangan bahasa anak tunarungu dapat menyebabkan anak tunarungu kurang memiliki persyaratan pokok komunikasi yang berbentuk bahasa lisan. Sehingga dalam mengekspresikan pikiran, perasaan dan kehendaknya mereka mengalami kendala. Kualitas keterampilan berbahasa dipengaruhi oleh kualitas dan jumlah kosakata yang dimiliki. Semakin banyak kosakata yang dikuasai maka semakin bagus juga kualitas keterampilan komunikasi dan bahasanya (NAILA MAULINA RAHMAWATI , 2018, t.t., 3).

Permanarian menjelaskan bahwa tunarungu merupakan istilah yang diberikan kepada orang yang mengalami gangguan pendengaran. Bila seorang kurang mampu mendengar suara dan sudah tidak bisa mendengarkan suara maka orang bisa dikatakan sebagai penyandang tunarungu. Disamping itu juga tunarungu sering disebut sebagai kata bisu/ tuli atau cacat pada fungsi pendengaran, sehingga dengan ketunaan tersebut tampak perbedaan dengan anak-anak yang lainya. Oleh karena sebab itu mereka perlu mendapat layanan dan bimbingan pendidikan secara khusus dalam mengembangkan potensi yang dimilikinya (Resti 2012, 350-51).

Anak berkebutuhan khusus yaitu anak yang mengalami gangguan baik secara jasmani maupun psikologinya. Sebagai contoh yaitu anak tunarungu yang mengalami kerusakan pada telinga bagian dalam akan terlihat pada psikis biasanya mengalami intelegnsi, perkembangan bahasa, kemampuan berpikir dan lambat belajar, serta perasaan tidak mampu dan sebagainya. Anak tunarungu menurut Efendi, anak yang merupakan anak yang memiliki hambatan fisik yakni gangguan mendengar (Pradipta 2020, 1). Tunarungu saat berkomunikasi sering merasa kesusahan dalam menyampaikan pesan dan memahami pesan sehingga membutuhkan bahasa yang sesuai dengan kebutuhanya yaitu dengan menggunakan bahasa isyarat. Dalam perkembangan Bahasa isyarat dikalangan tunarungu dibagi menjadi 2 bahasa isyarat yaitu SIBI (Sistem Isyarat Bahasa Indonesia) dan BISINDO (Bahasa Isyarat Indonesia). Dengan adanya perkembangan dua penggunaan Bahasa isyarat di Indonesia membuat tunarungu mengalami kesulitan dalam menentukan aksesbilitas dalam berkomunikasi apakah menggunakan BISINDO/SIBI (Mursita 2015, 222).

Menurut teori yang ada dibuku Efendi, kebenaran dalam suatu komunikasi diharapkan saat proses komunikasi itu berlangsung agar tujuan yang diharapkan dapat tercapai dan berlangsung agar tujuan yang diharapkan saat proses komunikasi itu berlangsung secara efektif (Pradipta 2020, 6). Apabila dilihat secara fisik, anak tunarungu tidaklah berbeda dengan anak yang bisa mendengar pada umumnya. Orang akan mengetahui bahwa anak yang menyandang ketunarunguan saat komunikasi, khususnya jika dituntut untuk berbicara, karena berbicaranya tanpa suara , atau dengan suara yang kurang jelas atau tidak jelas artikulasinya, 
1827 Strategi Mnemonic Sebagai Solusi Untuk Pengayaan Kosa Kata Pada Anak Tunarungu Di Sekolah Dasar-Zaenuri, Maemonah

DOI: https://doi.org/10.31004/basicedu.v5i4.1038

bahkan tidak berbicara tanpa suara, ataupun tidak bisa berbicara sama sekali, anak hanya berisyarat. (Bintoro 2011, 24).

Anak tunarungu adalah anak yang mengalami masalah atau gangguan pada organ pendengaranya sehingga mengakibatkan ketidakmampuan untuk mendengar, mulai dari tingkatan yang ringan sampai berat yang diklasifikasikan kedalam tuli , kurang dengar (Ganur, Bunga-Kiling, dan Kiling 2014, 2). Hendarmin mengatakan bahwa penderita tunarungu, kesulitan untuk mengembangkan kemampuan berbicara, sehingga mengalami hambatan pada saat berkomunikasi dan akhirnya menghambat perkembangan kepribadian, kecerdasan, dan penampilanya sebagai makhluk hidup sosial. (Bintoro 2011, 13).

Kata mnemonic bermula dari bahasa Yunani kuno, yakni dari kata mnemosyne yang artinya "dewi memori atau ingatan. Belajar secara mnemonic adalah nama lain dari belajar dengan jembatan keledai. Belajar cara ini memanfaatkan makna keterhubungan antara apa yang mudah dipahami dengan sesuatu yang dipelajari. (Wijaya 2012, 4). Mnemonic merupakan cara yang berguna untuk mempelajari fakta, perangkat atau sebuah alat. Mnemonic sendiri adalah strategi untuk meningkatkan memori dengan menggunakan rymess dan jingle, loci, cerita, atau teknik penghubung. Perangkat ini membantu memusatkan perhatian pada apa yang harus dipelajari dan memfasilitasi pencekalanya serta retrieval dan ingatan jangka panjang. Strategi mnemonic mengubah informasi yang dipelajari menjadi lebih bermakna, dengan menjalin hubungan antara informasi dan pengetahuan sebelumnya (Purnamasari 2018, 128).

Dari problematika penjelasan diatas peneliti memandang anak tunarungu sulit untuk mengembangkan pola komunikasinya sehingga berpengaruh dalam bergai hal baik dalam aspek kehidupan sehari-hari dan juga dalam segi dunia pendidikan dikarekan faktor berbahasa dan berkomunikasi, sosial, emosi, kognitif serta kecerdasan dalam dirinya. Sedangkan pendidikan sendiri sangat penting untuk setiap orang. Maka dari hal inilah bagaiamana kita sebagai seorang pendidik bisa memberikan pendidikan khsusus untuk anak-anak yang mengalami tunarungu. Dari hal inilah perlunya adanya strategi mnemonic untuk mengingat dan menghafal agar anak yang mengalami problematika seperti ini bisa tanggap dalam memperoleh ilmu pendidikan.

Berdasarkan pernyataan diatas terkait penelitian sebelumnya, yaitu penelitian yang dilakukan oleh Mariyatul Qibtiyah yang berjudul "Penerapan Strategi Mnemonic Acronim Terhadap Hasil Belajar Siswa Pelajaran Pai Materi Asmau'ul Husna Di Kelas X Sma Negeri 1 Tanjung Lago Kabupaten Banyuasin”, yang kemudian penelitian yang dilakukan oleh Wasmana yang berjudul "Strategi Mnemonic Untuk Peningkatan Prestasi Belajar Ips Siswa Kelas VI Pada Sekolah Dasar”, selanjutnya penelitian oleh Veneranda Suri Mappan, Edy Tandililing dan Ahmad Yani yang berjudul "Pengaruh Mnemonic Terhadap Daya Ingat dan Kemampuan Berpikir Kritis Mengenai Ukuran Dispersi Sebaran Data". Dan sedangkan yang belum dibahas terkait penelitian yaitu tentang bagaimana penerapan strategi mnemonic sebagai solusi untuk mengingat anak berkebutuhan khusus atau anak yang mempunyai problem tunarungu. Berangkat observasi diartikel jurnal dalam penelitian-penelitian sebelumnya maka peneliti tertarik untuk mengambil judul jurnal "Strategi Mnemonic Sebagai Solusi Pengayaan Kata Pada Anak Tunarungi Di Sekolah Dasar”.

Berdasarkan urain penelitian sebelumnya dan penelitian yang diambil oleh peneliti yaitu terkait judul penelitian yang dilakukan oleh Mariyatul Qibtiyah itu bertujuan untuk mellihat implementasi penerapan strategi mnemonic dengan menghafalkan secara cepat materi pelajaran asmaul husna, selanjutnya penelitian oleh Wasama bertujuan untuk meningkatkan prestasi hasil belajar siswa dalam mata pelajaran Ips, kemudian penelitian yang dilakukan oleh Verenanda, Edy dan Yani itu untuk melihat daya ingat dan siswa berfikir kritis dalam menghafalkan materi matematika tentang sebaran data. Dari perbedaan maupun persamaan terkait bahasan strategi mnemonic tentu bisa dilihat dari perbedaan maksud dan tujuan antara penelitian sebelumnya dan penelitian yang dilakukan oleh peneliti dikarenakan strategi ataupun tujuan akhir yang dimaksud bertujuan pada anak tunarungu.

Maka dari itu, terkait bahasan yang ada diatas pentingnya dari penelitian ini bertujuan untuk melihat penerapan strategi menghafal baik jangka pendek maupun jangka panjang dengan menggunakan strategi 
mnemonic utuk memperkaya kosa kata pada anak tunarungu. Dari tujuan ini contoh pengaplikasian yang harus dilakukan oleh guru yaitu, guru menyiapkan beberapa kosakata yang akan digunakan dalam proses pembelajaran, sebagai contoh kata ambulan, antri, astronot, dan bolpoint. Guru menuliskan kata tersebut pada karton dan memberikan gambar sebagai penjelas kata. Guru menempelkan kosakata pada bagian-bagian dinding kelas, pada bagian kiri dan kanan atau pada bagian belakang yang sering terlihat oleh siswa. Guru meminta siswa untuk berdiri mengikuti guru dan melafalkan kosakata yang diucapkan guru.

\section{METODE PENELITIAN}

Jenis metode penelitian yang digunakan dalam penelitian ini adalah studi kepustakaan atau literatur dengan pendekatan kualitatif deskriptif. Menurut Sugiyono, data kualitatif adalah data yang dinyatakan dalam bentuk kalimat, kata dan gambar. Jenis penelitian deskriptif yang digunakan adalah studi pustaka. Sumber data yang digunakan adalah studi kepustakaan dengan mencari sumber data baik berupa , artikel, buku jurnal ilmiah yang berkaitan dengan penelitian sebelumnya yang relevan. Teknik pengumpulan data yang digunakan adalah observasi, bahan yang akan diobservasi dalam penelitian ini adalah artikel jurnal yang berkaitan dengan strategi mnemonic dan anak tunarungu.

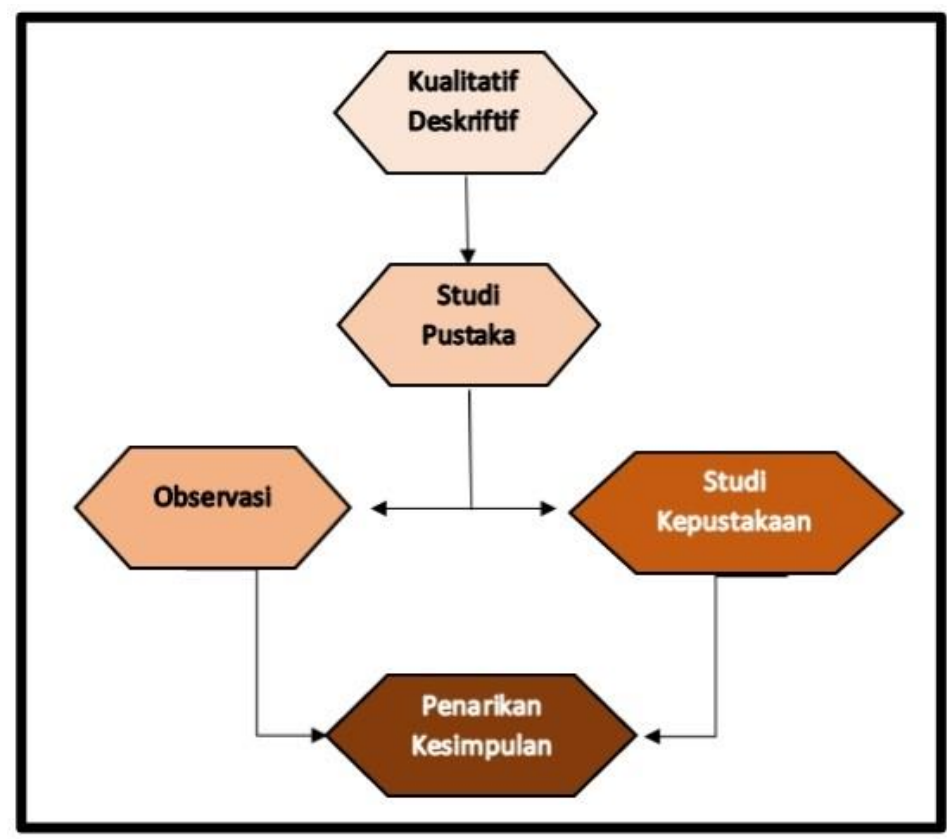

Gambar 1. Bagan penelitian litelatur

Litelatur yang dikaji dalam penelitian ini difokusnya tentang pengaruh strategi mnemonic yang bertujuan untuk daya mengingat dan menghafal pada anak berkebutuhan khusus yaitu anak tunarungu. Jumlah litalatur yang dikaji disini berjumlah empat tentang penelitian sebelumnya yang membahas strategi mnemonic. Dan yang menjadi alasan peneliti memilih bahasan ini karena betapa pentingnya pengaruh dari strategi mnemonic itu sendiri, $h$ al ini dilihat dari penelitian-penelitian yang sudah ada sebelumnya. Tolak ukur yang menjadi penetapan objek kajian ini adalah junal sudah sudah terakreditasi sinta, yang mana terbit dimulai tahun 2017 2020.

Dalam mengolah data dari penelitian ini yaitu mengolah bahan penelitian, landasan teori, telaah pustaka dan tinjauan teoritis. Tata cara dalam pengolahan penelitian ini, peneliti mencari penelitian sebelumnya dengan observasi, mereview, mencatat, dan mengumpulkan data yang relevan untuk dijadikan objek kajian ilmiah. Kemudian dalam keabsahan data yang digunakan adalah dengan ketekunan memahai bagaimana pentingnya strategi mnemonic ini, Dan juga menggunakan data triangulasi yang mana membandingkan dan mengecek informasi dari hasil observasi kajian pustaka. 
1829 Strategi Mnemonic Sebagai Solusi Untuk Pengayaan Kosa Kata Pada Anak Tunarungu Di Sekolah Dasar-Zaenuri, Maemonah

DOI: https://doi.org/10.31004/basicedu.v5i4.1038

\section{HASIL DAN PEMBAHASAN PENELITIAN}

Dalam Jurnal Quata (Sinta 5), 1 September 2017, penelitian yang dilakukan oleh Wasmana yang berjudul “Strategi Mnemonic Untuk Peningkatan Prestasi Belajar Ips Siswa Kelas VI Pada Sekolah Dasar”, bahwasanya dalam penelitian ini prestasi belajar yang disebut dalam penelitian ini yaitu perolehan nilai evaluasi siswa pada mata pelajaran Ips. Pokok permasalahan utama dalam penelitian ini adalah apakah strategi mnemonic bisa meningkatkan prestasi belajar Ips dengan menggunakan strategi mnemonic. Strategi mnemonic yang digunakan untuk menerima dan mengingat informasi baru. Ada dua syarat untuk melihat bagaimana seoerang individu belajar dan bagaimana mereka mengimplementasikan strategi-strategi belajar tertentu yaitu : pentingnya pengetahuan awal atau informasi baru, dan cara otak memproses pegetahuan awal atau informasi baru. Sejumlah ahli psikologi kognitif sudah mengembangkan apa yang mereka sebut pandangan pemrosesan informasi tentang arti pembelajaran. Dari sudut pandang ini, informasi masuk kedalam otak melalui indera-indera dan disimpan sementara didalam suatu ruang kerja yang disebut dengan memori jangka pendek. Dari memori jangka pendek itu sendiri kemudian dikirimkan ke dalam memori jangka panjang lalu disimpan sampai dipanggil kembali untuk penggunaan dikemudian hari. Dari hasil penelitian ini bahwasanya kegiatan penelitian ini diawali dari kajian teori dan lapangan, hal yang dilakukan selam proses pembelajaran berlangsung dikelas. Selanjutnya melakukan penjelasan penerapan strategi mnemonic. Penjelasan tersebut hanya disampaikan pada kelompok siswa yaitu melalui kelas. Kemudian selanjutnya peneliti memberikan soal evaluasi dengan soal yang sama pada siswa kelas eksperimen atau kelas control dengan secara acak, kegiatan ini dilakukan untuk mengetahui apakah mereka rasakan selama penerapan strategi mnemonic, menghapal materi IPS, dan menjawab soal evaluasi. Perwakilan siswa yang diwawancarai ditentukan dengan acak masing-masing satu orang siswa. Hasil penerapan strategi mnemonic pada pembelajaran IPS dikelas VI SDN Sinarjati menunjukkan bahwa siswa yang menggunakan strategi mnemonic menghafal materi pelajaran IPS prestasinya lebih baik dibandingkan dengan siswa yang tidak menggunakanya (Wasmana 2017, 49).

Dalam Jurnal For Youth, Sport \& Health Education, Oktober 2018, penelitian yang dilakukan oleh Rika Purnamasari yang berjudul "Strategi Pembelajaran Mnemonic Untuk Meningkatkan Memori Siswa" bahwasanya hasil dari penelitian ini banyaknya materi yang harus disimpan dalam memori otak menjadi salah satu gejala negatif yang menimbulkan masalah lupa. Dalam hal ini, perlu adanya upaya yang signifikan untuk meningkatkan memori ingatan siswa agar siswa bisa menguasai materi pembelajaran secara menyeluruh dengan mengantisipasi masalah lupa. Upaya untuk menyelesaikan permasalahan tersebut, salah satunya, dengan menggunakan strategi "Mnemonic", yang merupakan cara menghafal dengan mengasosiasikan kata-kata, gagasan atau ide dengan gambar-gambar yang menarik. Cara kerja strategi "Mnemonic" adalah mengaktikan fungsi otak kanan, dimana anak dilatih untuk membuat suatu cerita, imajinasi, lagu atau irama, dan gambar, sehingga suatu materi menjadi sesuatu yang unik, menarik, dan menyenangkan. Berdasarkan analisis data secara kuantitatif, ianya dapat ditarik kesimpulan bahwa strategi "Mnemonic" berpengaruh terhadap peningkatan memori siswa dalam proses belajar-mengajar di kelas (Purnamasari 2018, 125).

Dalam Jurnal Pendidikan dan Pembelajara, November 2019, penelitian yang dilakukan oleh Veneranda Suri Mappan, Edy Tandililing dan Ahmad Yani yang berjudul "Pengaruh Mnemonic Terhadap Daya Ingat dan Kemampuan Berpikir Kritis Mengenai Ukuran Dispersi Sebaran Data" bahwasanya Merujuk pada hasil penelitian yang telah dilakukan, maka dapat diambil kesimpulan bahwa Kemampuan belajar siswa menggunakan metode konvensional menghasilkan nilai yang rendah diakibatkan rumus yang terlampau banyak dan panjang, sehingga siswa sulit untuk mengingatnya. Apabila siswa kesulitan mengingat rumus yang ada, maka sulit untuk bisa mengerjakan soal-soal yang diberikan walaupun termasuk soal dengan tingkat kesulitan yang rendah. Daya ingat siswa dengan bantuan mnemonic menghasilkan proses pembelajaran yang lebih baik karena siswa tidak kesulitan dalam mengingat masing-masing rumus (Mappan, Tandililing, dan Yani 2019, 18).

Dalam Jurnal Pendidikan dan Pembelajaran Eduscope, Juni 2020, penelitian yang dilakukan oleh Eliza Verdianingsih yang berjudul "Strategi Mnemonic dalam Pembelajaran Matematika", bahwasanya hasil dari 
1830 Strategi Mnemonic Sebagai Solusi Untuk Pengayaan Kosa Kata Pada Anak Tunarungu Di Sekolah Dasar-Zaenuri, Maemonah

DOI: https://doi.org/10.31004/basicedu.v5i4.1038

penelitian ini strategi mnemonic berpengaruh untuk mengaktifkan otak kanan, dikarenakan anak dilatih untuk membuat suatu cerita, berimajinasi, lagu atau irama dan gambar sehingga suatu materi menjadi sesuatu yang unik, menarik dan menyenangkan. Dengan demikian anak lebih mudah dan lebih cepat mengingat dan menghafal. Informasi tersebut terjadi baik diingatan jangka pendek maupun jangka panjang. Dalam ingatan jangka pendek sendiri kapasitasnya dapat kita perluas kalua kita melakukan chunking terdapat informasi yang baru masuk, sedangkan dalam ingatan jangka panjang sendiri kapasitasnya berhubungan dengan skema subyek. Dengan demikian pengkodean informasi dalam kategori-kategori dapat mempermudah proses mengingat Kembali. Dalam penelitian ini strategi mnemonic bisa meningkatkan memori siswa, siswa dapat menghafal materi pelajaran, memberikan struktrur belajar untuk memperoleh informasi dengan baik, dan strategi mnemonic bermanfaat untuk meningkatkan memori dan memudahkan siswa dalam menangkap materi pelajaran lebih efektif dan menyenangkan (Verdianingsih 2020, 82).

Tabel 1

hasil analsisis penelitian strategi mnemonic

\begin{tabular}{|c|c|c|c|}
\hline Author \& Tahun \& Judul & Tujuan & Metode & Hasil \\
\hline $\begin{array}{l}\text { Wasama (2017), } \\
\text { "Strategi Mnemonic } \\
\text { Untuk Peningkatan } \\
\text { Prestasi Belajar Ips } \\
\text { Siswa Kelas VI Pada } \\
\text { Sekolah Dasar" }\end{array}$ & $\begin{array}{l}\text { Untuk mengingat } \\
\text { pelajaran ips dan } \\
\text { meningkatkan hasil } \\
\text { belajar siswa }\end{array}$ & $\begin{array}{l}\text { Menggunakan } \\
\text { metode eksperimen }\end{array}$ & $\begin{array}{l}\text { Hasil penerapan strategi } \\
\text { mnemonic pada } \\
\text { pembelajaran IPS dikelas VI } \\
\text { SDN Sinarjati menunjukkan } \\
\text { bahwa siswa yang } \\
\text { menggunakan strategi } \\
\text { mnemonic menghafal materi } \\
\text { pelajaran IPS prestasinya } \\
\text { lebih baik dibandingkan } \\
\text { dengan siswa yang tidak } \\
\text { menggunakanya }\end{array}$ \\
\hline $\begin{array}{l}\text { Rika Purnamasari, } 2018 \\
\text { "Strategi Pembelajaran } \\
\text { Mnemonic Untuk } \\
\text { Meningkatkan Memori } \\
\text { Siswa" }\end{array}$ & $\begin{array}{l}\text { Untuk mempermudah } \\
\text { dan cepat menghafal } \\
\text { dengan menggunakan } \\
\text { strategi mnemonic }\end{array}$ & $\begin{array}{l}\text { Analisis data secara } \\
\text { kuantitatif }\end{array}$ & $\begin{array}{l}\text { strategi "Mnemonic" } \\
\text { berpengaruh terhadap } \\
\text { peningkatan memori siswa } \\
\text { dalam proses belajar- } \\
\text { mengajar di kelas }\end{array}$ \\
\hline $\begin{array}{l}\text { Veneranda Suri Mappan, } \\
\text { Edy Tandililing dan } \\
\text { Ahmad Yani, (2019) } \\
\text { "Pengaruh Mnemonic } \\
\text { Terhadap Daya Ingat } \\
\text { dan Kemampuan } \\
\text { Berpikir Kritis } \\
\text { Mengenai Ukuran } \\
\text { Dispersi Sebaran Data" }\end{array}$ & $\begin{array}{l}\text { Untuk meningkatkan } \\
\text { memori ingatan siswa }\end{array}$ & $\begin{array}{l}\text { Analisis kualitatif } \\
\text { deskriptif }\end{array}$ & $\begin{array}{l}\text { berpengaruh terhadap } \\
\text { peningkatan memori siswa } \\
\text { dalam proses belajar- } \\
\text { mengajar di kelas }\end{array}$ \\
\hline $\begin{array}{l}\text { Eliza Verdianingsih } \\
\text { yang berjudul (2020) } \\
\text { "Strategi Mnemonic } \\
\text { dalam Pembelajaran } \\
\text { Matematika", }\end{array}$ & $\begin{array}{l}\text { Untuk mengingat dalam } \\
\text { jangka panjang }\end{array}$ & Analisis kuantitatif & $\begin{array}{l}\text { Dalam penelitian ini } \\
\text { strategi mnemonic bisa } \\
\text { meningkatkan memori } \\
\text { siswa, siswa dapat } \\
\text { menghafal materi pelajaran, } \\
\text { memberikan struktrur belajar } \\
\text { untuk memperoleh informasi } \\
\text { dengan baik, dan strategi } \\
\text { mnemonic bermanfaat untuk } \\
\text { meningkatkan memori dan } \\
\text { memudahkan siswa dalam } \\
\text { menangkap materi pelajaran }\end{array}$ \\
\hline
\end{tabular}




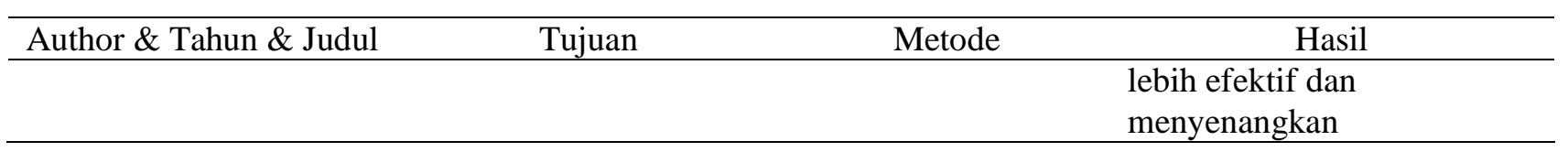

Dari beberapa penelitian terbukti bahwa strategi mnemonic ini jelas dapat meningkatkan ingatan . Budiman, meneliti tentang pengaruh pembelajaran dengan model mnemonic terhadap ketuntasan hasil belajar trigonometri. Hasil dari penelitian ini menunjukkan bahwa pembelajaran dengan model mnemonic dapat meningkatkan prestasi belajar matematika siswa pada topik yang memerlukan hafalan, seperti pada topik dasar trigonometri. Hasil observasi menunjukkan bahwa pembelajaran dengan model mnemonic membuat suasana kelas menyenangkan sehingga siswa antusias dalam mendengarkan pembelajaran menghafal yang disampaikan oleh guru. Hal ini antara lain disebabkan beberapa hal yang sebelumnya sukar diingat, tetapi dengan menggunakan mnemonic dapat lebih mudah diingat, sedangkan cara-cara yang digunakan dalam peningkatan daya ingat ini suatu teknik yang menuntut kemampuan otak untuk menghubungkan kata-kata, ide dan khassyalan (Verdianingsih 2020, 80).

Berdasarkan hasil dari analisis dan tabel beberapa penelitian tentang strategi mnemonic diatas, yang pertama penelitian yang dilakukan oleh Wasama menunjukkan bahwa siswa yang menggunakan strategi mnemonic menghafal materi pelajaran IPS prestasinya lebih baik dibandingkan dengan siswa yang tidak menggunakanya. dari kedua perbedaan dan persamaan tentang hasil yang dilakukan oleh kedua peneliti sebelumnya yang membahas tentang strategi mnemonic dapat disimpulkan bahwasanya strategi mnemonic sangat berpengaruh pada ingatan siswa dimulai dari jangka pendek dan menuju jangka panjang. Oleh sebab itu maka stategi mnemonic yang dilakukan oleh peneliti tentang strategi mnemonic untuk anak tunarungu sangat berpengaruh terhadap siswa, dikarenakan anak tunarungu sangat terbatas kosa kata yang dimilikinya. Maka dengan menggunakan strategi ini anak tunarungu akan lebih banyak mempunyai kosa kata yang akan dimilikinya. kedua penelitian yang dilakukan oleh Rika Purnamasari yaitu bahwa strategi "Mnemonic" berpengaruh terhadap peningkatan memori siswa dalam proses belajar-mengajar di kelas. Ketiga penelitian yang dilakukan oleh Verenanda dan Edy bahwasanya daya ingat siswa dengan bantuan mnemonic menghasilkan proses pembelajaran yang lebih baik karena siswa tidak kesulitan dalam mengingat masing-masing rumus. Keempat penelitian penelitian yang dilakukan oleh Eliza menunjukkan bahwa pembelajaran dengan model mnemonic dapat meningkatkan prestasi belajar matematika siswa pada topik yang memerlukan hafalan, seperti pada topik dasar trigonometri. Dari hal ini bahwasanya dapat dilihat penerapan strategi mnemonic sangat baik digunakan oleh guru dalam mengajar siswa tunarungu untuk memperkaya kosa katanya.. sebagai contoh teori yang dijelaskan oleh Hapsari, menurutnya terdapat beberapa metode dari strategi mnemonic adalah sebagai berikut :

Tabel 2

Strategi mnemonic

\begin{tabular}{|c|c|c|c|c|}
\hline No & Strategi & Definisi & Perkembangan & Contoh \\
\hline 1. & $\begin{array}{l}\text { Bantuan } \\
\text { eksternal }\end{array}$ & $\begin{array}{l}\text { Diingatkan oleh sesuatu } \\
\text { yang berada diri }\end{array}$ & $\begin{array}{l}\text { Usia } 6 \text { tahun bias } \\
\text { melakukannya, usia } 8 \\
\text { tahun terbiasa } \\
\text { melakukannya. }\end{array}$ & $\begin{array}{l}\text { Mengajarkan anak } \\
\text { melalui mencatat } \\
\text { jadwal pembelajaran. }\end{array}$ \\
\hline 2. & Rehearsal & $\begin{array}{l}\text { Pengulangan } \\
\text { disengaja }\end{array}$ & $\begin{array}{l}\text { Usia } 6 \text { tahun dapat } \\
\text { diajarkan, usia } 7 \text { tahun } \\
\text { melakukan spontan }\end{array}$ & $\begin{array}{l}\text { mengulang-ulang } \\
\text { kata untuk di ingat. }\end{array}$ \\
\hline 3. & $\begin{array}{l}\text { Organisasi (systematic } \\
\text { organizer) }\end{array}$ & $\begin{array}{l}\text { Mengelompokkan } \\
\text { berdasarkan kategori }\end{array}$ & $\begin{array}{l}\text { Usia } 10 \text { tahun bias } \\
\text { melakukannya }\end{array}$ & $\begin{array}{l}\text { Mencoba } \\
\text { mengelompokkan } \\
\text { kata melalui huruf }\end{array}$ \\
\hline
\end{tabular}


1832 Strategi Mnemonic Sebagai Solusi Untuk Pengayaan Kosa Kata Pada Anak Tunarungu Di Sekolah Dasar-Zaenuri, Maemonah

DOI: https://doi.org/10.31004/basicedu.v5i4.1038

\begin{tabular}{|c|c|c|c|c|}
\hline No & Strategi & Definisi & Perkembangan & Contoh \\
\hline & & & & $\begin{array}{l}\text { abjad. Contoh huruf } \\
\text { A: ambil, ada, apa }\end{array}$ \\
\hline & Elaborasi & $\begin{array}{l}\text { Membuat asosiasi mental } \\
\text { aitem dengan sesuatu yang } \\
\text { lain yang mudah diingat } \\
\text { dengan singkat atau } \\
\text { dengan membuat cerita }\end{array}$ & $\begin{array}{l}\text { Anak-anak biasanya } \\
\text { masih dibantu, anak } \\
\text { yang lebih besar bisa } \\
\text { melakukan sendiri }\end{array}$ & $\begin{array}{l}\text { Mengingat warna } \\
\text { pelangi merah, } \\
\text { jingga, kuning, hijau, } \\
\text { biru, nila, ungu, } \\
\text { dengan } \\
\text { "mijikuhibiniu", }\end{array}$ \\
\hline & Imagery & $\begin{array}{l}\text { Metode kata kunci dengan } \\
\text { mengkaitkan kata yang } \\
\text { ingin dipelajari dengan } \\
\text { kata yang mirip yang } \\
\text { sudah dikenal }\end{array}$ & $\begin{array}{lr}\text { Digunakan di usia } \\
\text { pertengahan dan akhir } \\
\text { masa kanak-kanak, } \\
\text { terutama dalam } \\
\text { mempelajari bahasa } \\
\text { asing }\end{array}$ & $\begin{array}{l}\text { Mengingat nama } \\
\text { ibukota Maryland } \\
\text { dengan kata kunci } \\
\text { Marry }\end{array}$ \\
\hline & Method of loci & $\begin{array}{l}\text { Mengingat dengan cara } \\
\text { mengasosiasikan hal-hal } \\
\text { yang akan diingat pada } \\
\text { suatu rangkaian loci atau } \\
\text { tempat-tempat tertentu. }\end{array}$ & $\begin{array}{l}\text { Berkembang di usia } \\
\text { pertengahan dan akhir } \\
\text { masa kanak-kanak }\end{array}$ & $\begin{array}{l}\text { Mengingat hal-hal } \\
\text { yang akan diingat } \\
\text { berdasarkan tempat- } \\
\text { tempat tertentu yang } \\
\text { mudah dikenal. }\end{array}$ \\
\hline & Sistem abjad & $\begin{array}{l}\text { Mengingat kata dengan } \\
\text { mengorganisasikan kata } \\
\text { berdasar abjad tertentu } \\
\text { diurutkan dari A hingga } \mathrm{Z} \\
\text { seperti kamus }\end{array}$ & $\begin{array}{l}\text { Di usia pertengahan } \\
\text { dan akhir anak-anak }\end{array}$ & $\begin{array}{l}\text { Mempelajari } \\
\text { beberapa kosakata } \\
\text { berdasar urutan abjad }\end{array}$ \\
\hline
\end{tabular}

Dalam penelitian sebelumnya yang dilakukan oleh Deni Nofita yang berjudul "Penerapan Strategi Mnemonic Keyword Dalam Meningkatkan Pemahaman Kosa Kata Siswa Tunarungu Di SLB Lembang”, hasil dari penelitian ini berpengaruh terhadap pemahaman kosa kata siswa tunarungu A dan DL yang berusia 15 tahun. Kemampuan pemahaman kosa kata tersebut meningkat ingatan dan pemahamanya setelah dilakukan dengan menggunakan strategi mnemonic. Selanjutnya penelitian sebelumnya yang dilakukan oleh Nafi'atul Imtiyaz yang berjudul "Pengaruh Metode Mnemonic Terhadap Kemampuan Mengingat dan Menyusun Kalimat Berbasis Eyd Siswa Tunarunguu kelas V SLB Surakarta”, hasil dari penelitian ini adalah metode dengan menggunakan strategi mnemonic berpengaruh terhadap kemampuan mengingat dan menyusun kalimat Eyd. Sedangkan yang menjadi objek kajian peneliti yaitu strategi mnemonic yaitu sebagai solusi untuk pengayaan kosa kata pada anak tunarungu disekolah dasar.

Dari keterangan diatas yang menjadi perbedaan dalam penelitian sebelumnya dan penelitian yang dilakukan oleh peneliti, yang pertama oleh Deni Nofita, penelitian ini fokus untuk meningkatkan pemahaman kosa kata pada anak tunarungu, kemudian Nafi'atul Imtiyaz fokus terhadap menghafal dan menyusun kalimat Eyd, sedangkan peneliti fokus tentang bagaimana strategi atau langkah yang digunakan strategi mnemonic untuk mengingat dan menghafal pada anak tunarungu. Berdasarkan semuai urain diatas mulai dari penelitian sebelumnya tentang data dan tabel yang ada yaitu "mnemonic" dan "tunarungu" strategi mnemonic ini sangat baik untuk metode mengingat ataupun menghafal. Dari hal ini dan penjelasan yang ada mnemonic sangat baik juga diterapkan pada anak berkebutuhan khsusu/ anak tunarungu. 
1833 Strategi Mnemonic Sebagai Solusi Untuk Pengayaan Kosa Kata Pada Anak Tunarungu Di Sekolah Dasar-Zaenuri, Maemonah

DOI: https://doi.org/10.31004/basicedu.v5i4.1038

\section{KESIMPULAN}

Penggunaan strategi mnemonic keyword sangat membantu untuk pemerolehan dan pengayaan kosakata pada anak tunarungu sangat berpengaruh pada ingatan siswa dimulai dari jangka pendek dan menuju jangka Panjang. stategi mnemonic untuk anak tunarungu berpengaruh terhadap siswa, dikarenakan anak tunarungu sangat terbatas kosa kata yang dimilikinya. Maka dengan menggunakan strategi ini anak tunarungu akan lebih banyak mempunyai kosa kata yang akan dimilikinya. strategi mnemonic juga berpengaruh terhadap peningkatan memori siswa dalam proses belajar-mengajar di kelas dan daya ingat siswa dengan bantuan mnemonic menghasilkan proses pembelajaran yang lebih baik.

\section{DAFTAR PUSTAKA}

Abdullah, Nandiyah. 2013. "Mengenal Anak Berkebutuhan Khusus," no. 86: 10.

Bintoro, Totok. 2011. "Kemampuan Komunikasi Anak Tunarungu.” Perspektif Ilmu Pendidikan 23 (XIV): 12 40.

Chaer, Abdul. 2009. Psikolinguistik: kajian teoretik. PT. Rineka Cipta.

Christine, Jelyna. 2016. "Pemerolehan Bahasa Anak Tunarungu.” Jurnal Penelitian dan Pengembangan Pendidikan Anak Usia Dini 3 (2): 95-104.

Ganur, Maria, Beatriks Bunga-Kiling, dan Indra Kiling. 2014. "Pola komunikasi anak usia dini tunarungu bukan bawaan." Jurnal Transformasi Edukasi 3 (Januari): 63-69.

HarwantiNoviandari, dan Agus Mursidi. 2019. "Identifikasi Dini Guna Mengoptimalkan Kemampuan Bahasa Pada Anak Tuna Rungu Usia Pra Sekolah.” Jurnal Psikologi: Jurnal Ilmiah Fakultas Psikologi Universitas Yudharta Pasuruan 6 (1): 39-53.

Mappan, Veneranda Suri, Edy Tandililing, dan Ahmad Yani. 2020. "Pengaruh Mnemonic Terhadap Daya Ingat Dan Kemampuan Berpikir Kritis Mengenai Ukuran Dispersi Sebaran Data." Jurnal Pendidikan Dan Pembelajaran Khatulistiwa 9 (7).

"Model Pembelajaran Langsung Bermedia Word Wall Terhadap Pemahaman Kosakata Anak Tunarungu Kelas I Di Sdlb-B | Naila Maulina Rahmawati | Jurnal Pendidikan Khusus.” t.t.

Mursita, Rohmah Ageng. 2015. "Respon Tunarungu Terhadap Penggunaan Sistem Bahasa Isyarat Indonesa (SIBI) Dan Bahasa Isyarat Indonesia (Bisindo) Dalam Komunikasi." INKLUSI Journal of Disability Studies 2 (2): 221-32.

Pradipta, Rizqi Fajar. 2020. "Analisis Penyebab Kesulitan Anak Tunarungu Dalam Menyusun Kalimat Sederhana." Jurnal Orthopedagogik 1 (2): 36-44.

Purnamasari, Rika. 2018. "Strategi Pembelajaran Mnemonic untuk Meningkatkan Memori Siswa." SIPATAHOENAN 4 (2).

Resti, Aulia-. 2012. "Meningkatkan Kemampuan Membaca Pemahaman Pada Anak Tunarungu." Jurnal Penelitian Pendidikan Khusus 1 (2).

Verdianingsih, Eliza. 2020. "Strategi Mnemonic Dalam Pembelajaran Matematika." Eduscope: Jurnal Pendidikan, Pembelajaran, Dan Teknologi 6 (1): 78-85.

Wasmana, Wasmana. 2017. "Strategi Mnemonic Untuk Peningkatan Prestasi Belajar IPS Siswa Kelas VI Sekolah Dasar (Studi Eksperimen Terhadap Siswa Kelas VI SDN Sinarjati Tahun Pelajaran 2015/2016).” QUANTA 1 (1): 43-52.

Wijaya, Erwin Kurnia. 2012. "Pemanfaatan Modul Mnemonic (Modul Ingatan) Dalam Pembelajaran Program Paket C Untuk Meningkatkan Hasil Belajar.” Jurnal Pendidikan Luar Sekolah 8 (1).

Winarsih, Murni. 2010. "Pembelajaran Bahasa Bagi Anak Tunarungu.” Perspektif Ilmu Pendidikan 22 (XIII): 103-13. 